\title{
Atrial Natriuretic Peptide Measurement
}

National Cancer Institute

\section{Source}

National Cancer Institute. Atrial Natriuretic Peptide Measurement. NCI Thesaurus. Code C74886.

The determination of the amount of atrial-natriuretic peptide present in a sample. 